\title{
Předsoutěžní redukce tělesné hmotnosti a její vliv na tělesné složení
}

\section{Precontest weight loss and its effect on body composition}

\author{
Klára Coufalová, Ivana Kinkorová, Lucia Malá, Jan Heller
}

Fakulta tělesné výchovy a sportu Univerzity Karlovy v Praze

\begin{abstract}
Abstrakt:
Cílem naši studie bylo sledování změn jednotlivých komponent tělesného složenív důsledku redukce tělesné hmotnosti u judistů. Tato předsoutěžni redukce hmotnosti je obecně v úpolových sportech velmi častá a mnohdy i velmi výrazná, což může mít negativní dopad nejen na výkon, ale i zdraví závodníka.

Sledovaný soubor tvořilo 11 judisti̊ ve věku 17 - 27 let patřicich do reprezentace České republiky. Celkově se měřni parametrů tělesného složeni skládalo ze dvou částí, první část probihala pred redukci tělesné hmotnosti, tedy za běžné hmotnosti probandů, druhá část potom na konci redukce tělesné hmotnosti. K měření tělesného složení byl použit multifrekvenční bioimpedanční analyzér BIA 2000 - M.

$Z$ výsledků naši studie vyplývá, že rychlá intenzivní redukce hmotnosti se projeví v různé míre ve všech parametrech složeni těla. U daného souboru došlo ke snížení tělesné hmotnosti v průměru o 4,7 \% (prüměrně $o 3,8 \mathrm{~kg}$ ), príčemž hmotnostní úbytek se pohyboval v rozmezi od 1,6 kg do 8,1 kg. Největši zmény v jednotlivých parametrech tělesného složení jsme zaznamenali u extracelulární tekutiny (ECW), kde došlo k poklesu tohoto parametru v prüměru o 13,8\%, přičemž celková tělesná voda (TBW) se snižila o 6,0\%. Došlo také ke snižení množství tuku o 13,2\%, množství extracelulární hmoty (ECM) o 9,8\%, poměr ECM/BCM se snižil o 8,9\% a množství tukuprosté hmoty (FFM) kleslo o 4,0\%. Pouze u intracelulární tekutiny (ICW) jsme zaznamenali mírný vzestup o 1,4\%, což může být zapřičiněno redistribucí tělních tekutin.
\end{abstract}

Změny v jednotlivých parametrech tělesného složeni byly statisticky $i$ věcně významné.

\section{Abstract:}

The aim of our study was to monitor changes in individual components of body composition due to reduction in body weight in judo. This precontest weight reduction is very common in combat sports and it can have negative impact not only on performance but also on health.

Research group consisted of 11 judoists at the age of 17-27 years belonging to the representation of the Czech Republic. The measurement of body composition had two parts; the first was before body weight reduction and the second part at the end of body weight reduction. For the measurement of body composition we used multifrequency bioimpedance analyzer BIA 2000 - M. The results of our study show that rapid intensive weight reduction is reflected in varying degrees in all parameters of body composition. We noticed a reduction of body weight by an average of $4.7 \%$ (approximately $3.8 \mathrm{~kg}$ ), the weight loss ranged from $1.6 \mathrm{~kg}$ to $8.1 \mathrm{~kg}$. The greatest changes in the parameters of body composition were detected in the extracellular water (ECW), there was a decrease of this parameter on average by $13.8 \%$, while total body water (TBW) decreased by $6.0 \%$. There was also a reduction in the amount of body fat by $13.2 \%$, the amount of extracellular mass (ECM) decreased by $9.8 \%$, the ratio of ECM/BCM by $8.9 \%$ and the amount of fat-free mass (FFM) decreased by $4.0 \%$. Only in intracellular water (ICW), we noticed a slight increase by $1.4 \%$, which may be due to the redistribution of body fluids.

Changes of particular parameters of body composition were statistically and substantively significant.

Klíčová slova: judo, redukce tělesné hmotnosti, tělesné složení, bioelektrická impedance

Key words: judo, body weight reduction, body composition, bioelectrical impedance

Řešeno s podporou Výzkumného záměru MŠMT ČR MSM 0021620864 a Specifického vysokoškolského výzkumu 2013 267603 a v rámci Programu rozvoje vědnich oblastí na Univerzitě Karlově č. P38 Biologické aspekty zkoumáni lidského pohybu. 


\section{ÚVOD}

Všechny úpolové sporty lze charakterizovat snahou o účelné využití složitých dynamických stereotypů, technicko-taktických činností k přemožení protivníka (Havlíčková a kol., 1999). Judo, podobně jako řadu dalších bojových sportů, řadíme do skupiny rychlostně-silových sportů. Vyžaduje vysokou úroveň kondičních schopností a je velice náročné na sladění složitých pohybů, rovnováhu, orientaci v prostoru a rychlost reakce. Judistický výkon vyžaduje vysoké rezervy anaerobní vytrvalosti a kapacity s dobrou úrovní aerobního systému. Z pohybových schopností sehrává při zápase důležitou úlohu síla, především vytrvalost v dynamické síle a statická síla trupu a paží. Rychlost v judu má velký význam ve spojení s reakční rychlostí na dotykové podněty. Obratnost jako další z pohybových schopností se rozvíjí ve vztahu k technice chvatu a projevuje se ve variabilitě, přizpůsobivosti techniky odlišnému vzrůstu, pohybovým návykům a dalším vlastnostem soupeře (Štěpánek a kol., 1990).

Protože sportovní výkon je zde ovlivňován tělesnou hmotností závodníka, jsou soutěže rozděleny do různých hmotnostních kategorií. Proto je třeba kontrolovat a udržet určitou tělesnou hmotnost, ale i nízké zastoupení tělesného tuku. Určitá ohraničená hmotnost závodníka je tedy podmínkou startu v soutěži, ale závodníci mají běžně větší tělesnou hmotnost než tu, ve které startují. Horswill (2009) uvádí, že 70-80\% judistů bez ohledu na pohlaví snižuje svou tělesnou hmotnost pro zařazení do nižší hmotnostní kategorie. A právě tato rychlá redukce hmotnosti před závody je velmi diskutovaný problém. Je nutné si uvědomit, že existují rizika negativního dopadu těchto redukčních režimů na zdraví a výkonnost $\mathrm{v}$ př́ípadě, že redukce tělesné hmotnosti je vedena do extrému. Ransone \& Hughest (2004) ve své studii na zápasnících $(n=78)$ uvádí, že rozdíl mezi soutěžní tělesnou hmotností a aktuální tělesnou hmotností 24 hodin před soutěží může představovat až $6,60 \%$.

Nejčastějším způsobem tohoto nárazovitého snižování tělesné hmotnosti před soutěží je snižování tělesné hmotnosti za pomoci ztrát vody dehydratací, kde často dochází nejen ke snížení celkové vody v těle, ale i ke snížení aktivní složky (Forbes, 1987). Kromě úbytků hmotnosti dochází tedy také ke snížení svalové síly, a tím klesá i doba, po kterou je sportovec schopen podávat intenzivnější výkony. Současně bylo zjištěno i snížení množství obíhající krve, což se projevuje snížením výkonnosti srdce při maximálním i středním výkonu. Vzrůstá tepová frekvence, zhoršují se funkce oběhové a dýchací. Dochází i k poruše termoregulačních pochodů. Nadbytečné teplo je z těla hưře odváděno, a proto hrozí nebezpečí přehřátí. Dále klesá průtok krve ledvinami a snižuje se i jejich funkce, a tím vzniká nebezpečí usazování některých látek v ledvinách. Současně rapidně klesá i množství solí. Tyto změny vedou ke snížení výkonnosti sportovce a mohou i v některých př́ípadech při častém opakování ohrozit jeho vývoj a zdravotní stav. Jejich nebezpečnost se zvyšuje především u mladého organismu (Nedorostová, 1977).

Naše práce se proto zabývá sledováním vlivu redukce tělesné hmotnosti na závodníka z hlediska tělesného složení, nebot' tělesné složení je nejen jedním z nejdůležitějších ukazatelů vývojového stupně v průběhu ontogeneze, ale dále i úrovně zdraví, tělesné zdatnosti a výkonnosti a stavu výživy (Pařízková, 1998). Informace o tělesném složení se kromě fyziologických profilů mohou použít také k odhadu optimální tělesné hmotnosti sportovce nebo právě v úpolových sportech pro zařazení do soutěžních hmotnostních kategorií (Heyward, 1996). Pro sportovce může být měření tělesného složení a sledování jeho změn významným přínosem také pro hodnocení efektu tréninkového procesu (Sinning, 1996; Ishiguro et al., 2005).

\section{METODIKA}

\section{Soubor}

Testování se zúčastnilo 11 závodníků české seniorské reprezentace ve věkovém rozmezí 17-27 let. Všichni probandi byli měřeni dvakrát a to jednak před redukcí tělesné hmotnosti, tak i po redukci (tj. ráno před oficiálním vážením v den soutěže).

$\mathrm{V}$ souboru ( $\mathrm{n}=11$, průměrný věk $=21,5 \pm 3,5$ let) byla průměrná tělesná výška $180,0 \pm 5,9 \mathrm{~cm}$, průměrná tělesná hmotnost $80,6 \pm 11,3 \mathrm{~kg}$ a průměrná hodnota BMI $24,7 \pm 2,1 \mathrm{~kg} \cdot \mathrm{m}^{-2}$. 
Tab. 1. Základní somatometrické charakteristiky

\begin{tabular}{|c|c|c|c|c|}
\hline Proband & Věk [let] & $\begin{array}{c}\text { Tělesná výška } \\
{[\mathbf{c m}]}\end{array}$ & $\begin{array}{c}\text { Tělesná } \\
\text { hmotnost }[\mathbf{k g}]\end{array}$ & $\begin{array}{c}\text { Hmotnostní } \\
\text { kategorie }\end{array}$ \\
\hline 1 & 19 & 178,0 & 76,0 & $-73 \mathrm{~kg}$ \\
\hline 2 & 26 & 179,0 & 85,0 & $-81 \mathrm{~kg}$ \\
\hline 3 & 20 & 190,0 & 94,5 & $-90 \mathrm{~kg}$ \\
\hline 4 & 27 & 176,0 & 82,0 & $-81 \mathrm{~kg}$ \\
\hline 5 & 24 & 181,5 & 76,7 & $-73 \mathrm{~kg}$ \\
\hline 6 & 26 & 190,4 & 104,5 & $-100 \mathrm{~kg}$ \\
\hline 7 & 21 & 178,5 & 81,0 & $-73 \mathrm{~kg}$ \\
\hline 8 & 18 & 175,0 & 69,5 & $-66 \mathrm{~kg}$ \\
\hline 9 & 20 & 184,0 & 84,6 & $-81 \mathrm{~kg}$ \\
\hline 10 & 17 & 170,0 & 62,8 & $-60 \mathrm{~kg}$ \\
\hline 11 & 18 & 178,0 & 69,9 & $-66 \mathrm{~kg}$ \\
\hline Průměr \pm SD & $\mathbf{2 1 , 5} \pm \mathbf{3 , 5}$ & $\mathbf{1 8 0 , 0} \pm \mathbf{5 , 9}$ & $\mathbf{8 0 , 6} \pm \mathbf{1 1 , 3}$ & - \\
\hline
\end{tabular}

\section{Metody}

Obecně lze parametry tělesného složení stanovovat množstvím metod, které se liší jak přístrojovou a personální náročností, tak i přesností stanovení sledovaných dat (Roche et al., 1996). Jako nejvhodnější pro hodnocení tělesného složení se v tomto výzkumu jeví bioimpedanční metoda. Jde o moderní, neinvazivní, rychlou a relativně levnou nepřímou metodu pro určení dvoukomponentového modelu tělesného složení jak $\mathrm{v}$ laboratorních, tak i $\mathrm{v}$ terénních podmínkách. Tato metoda je založena na rozdílech $\mathrm{v}$ šíření střídavého elektrického proudu nízké intenzity biologickými strukturami.

K našemu výzkumu byl použit multifrekvenční bioimpedanční analyzátor BIA 2000 - M (Datainput, 2004) s tetrapolárním uspořádáním elektrod měřící na frekvencích 1, 5, 50 a $100 \mathrm{kHz}$. Sledovány byly následující parametry: celková tělesná voda (TBW), extracelulární (ECW) a intracelulární (ICW) voda, tukuprostá hmota (FFM) - absolutní i relativní hodnota, \% tělesného tuku (FM), množství extracelulární (ECM) a buněčné (BCM) hmoty (vč. relativní hodnoty - v přepočtu na $\mathrm{kg}$ tělesné hmotnosti) a jejich vzájemný poměr.

\section{Analýza dat}

Pro popis souboru jsme použili základní statistické charakteristiky - aritmetický průměr a směrodatnou odchylku. K porovnání výsledků celého souboru jsme použili párový t-test. Významnost rozdílu byla posuzována na standardní hladině významnosti $\alpha=0,05$. Za věcně významný rozdíl jsme považovali hodnoty $\omega^{2} \geq 0,1$.

Při přepočtu jednotlivých nepřímo měřitelných parametrů tělesného složení jsme vycházeli z př́islušných predikčních rovnic softwaru (Data Input, 2004).

\section{VÝSLEDKY}

Ve sledovaném souboru jsme zaznamenali průměrné množství celkové tělesné vody (TBW) 56,3 \pm 7,7 1, což představuje 69,9\% z celkové tělesné hmotnosti. Intracelulární tekutina (ICW) představovala průměrně 29,5 \pm 3,0 1, tj. 52,4 \% TBW, extracelulární tekutina (ECW) 26,8 \pm 7,1 1 tj. 47,6 \% TBW. Hodnota tukuprosté hmoty (FFM) představovala v průměru 88,38 \% tělesné hmotnosti. Procentuální zastoupení tukové hmoty bylo v průměru $12,9 \pm 3,0 \%$.

Vlivem redukce se tělesná hmotnost snížila $\mathrm{v}$ průměru o $3,9 \pm 1,6 \mathrm{~kg}$ (tj. v průměru o $4,7 \%$ tělesné hmotnosti), přičemž zaznamenaný hmotnostní úbytek se pohyboval v rozmezí od 1,6 kg do 8,1 kg. Ke změnám 
došlo i ve všech dalších sledovaných parametrech tělesného složení. Výrazný rozdíl jsme zjistili v zastoupení tělesných tekutin. Množství celkové tělesné vody (TBW) kleslo o 3,4 1 (tj. o 6,0 \%, rel. 4,2 \% těl. hmotnosti), přičemž množství extracelulární vody (ECW) kleslo o 3,7 l (tj. o 13,8 \%), zatímco množství intracelulární vody (ICW) se zvýšilo o 0,4 1 (tj. o 1,4\%). Tukuprostá hmota (FFM) se snížila v průměru o 2,8 kg (tj. o 4,0 \%) a množství tuku kleslo z $12,9 \pm 3,0 \%$ na $11,2 \pm 2,9 \%$.

Také u ostatních parametrů tělesného složení jsme zaznamenali významné změny. Srovnání vstupních (tj. před redukcí tělesné hmotnosti) a výstupních (tj. na konci redukce tělesné hmotnosti) parametrů tělesného složení měřených př́strojem BIA 2000 - M je uvedeno v tab. 2.

Tab. 2. Vstupní a výstupní parametry tělesného složení (průměr $\pm S D$ )

\begin{tabular}{|c|c|c|c|c|c|c|}
\hline & \multicolumn{6}{|c|}{ MUŽI ( n=11) } \\
\hline & $\begin{array}{l}\text { Vstup - } \\
\text { průměr }\end{array}$ & $\begin{array}{l}\text { Výstup - } \\
\text { průměr }\end{array}$ & \multicolumn{2}{|c|}{ Rozdíl } & $\mathbf{t}$ & $\omega^{2}$ \\
\hline Tělesná hmotnost [kg] & $80,6 \pm 11,3$ & $76,8 \pm 10,7$ & $-3,8$ & $4,7 \%$ & $7,252 *$ & 0,82 \\
\hline BMI $\left[\mathrm{kg} \cdot \mathrm{m}^{-2}\right]$ & $24,7 \pm 2,1$ & $23,4 \pm 2,2$ & $-1,3$ & $5,3 \%$ & $8,920 *$ & 0,88 \\
\hline LBM $[\mathrm{kg}]$ & $75,5 \pm 8,4$ & $72,3 \pm 9,1$ & $-3,2$ & $4,2 \%$ & $5,651 *$ & 0,74 \\
\hline ECM $[\mathrm{kg}]$ & $31,6 \pm 5,2$ & $28,5 \pm 4,4$ & $-3,1$ & $9,8 \%$ & $4,551^{*}$ & 0,64 \\
\hline $\mathrm{BCM}[\mathrm{kg}]$ & $44,6 \pm 4,3$ & $43,8 \pm 5,7$ & $-0,8$ & $1,8 \%$ & 0,152 & $-0,09$ \\
\hline $\mathrm{ECM} / \mathrm{BCM}$ & $0,720 \pm 0,104$ & $0,656 \pm 0,078$ & $-0,064$ & $8,9 \%$ & $2,512 *$ & 0,33 \\
\hline TBW [1] & $56,3 \pm 7,7$ & $52,9 \pm 6,7$ & $-3,4$ & $6,0 \%$ & $4,978 *$ & 0,68 \\
\hline ICW [1] & $29,5 \pm 3,0$ & $29,9 \pm 3,2$ & $+0,4$ & $1,4 \%$ & $-0,256$ & $-0,09$ \\
\hline ECW [1] & $26,8 \pm 7,1$ & $23,1 \pm 4,9$ & $-3,7$ & $13,8 \%$ & $2,291 *$ & 0,28 \\
\hline FFM $[\mathrm{kg}]$ & $70,6 \pm 7,8$ & $67,8 \pm 7,3$ & $-2,8$ & $4,0 \%$ & $2,938^{*}$ & 0,41 \\
\hline Tuk [\%] & $12,9 \pm 3,0$ & $11,2 \pm 2,9$ & $-1,7$ & $13,2 \%$ & $5,248 *$ & 0,75 \\
\hline
\end{tabular}

$* \mathrm{p}<0,05$

Legenda:

BMI - Body Mass Index

LBM - Lean Body Mass

ECM - Extracellular Mass
BCM - Body Cell Mass

$\mathrm{ECM} / \mathrm{BCM}$ - poměr ECM/BCM

TBW - Total Body Water
ICW - Intracellular Water

ECW - Extracellular Water

FFM - Fat Free Mass $\mathrm{t}$ - testovací kritérium, párový $\mathrm{t}$-test

$\omega^{2}-$ size effect, věcná významnost

Z hlediska statistické i věcné významnosti byl zjištěn významný rozdíl mezi vstupními a výstupními hodnotami u všech parametrů tělesného složení kromě buněčné hmoty $(\mathrm{BCM})$ a intracelulární tekutiny (ICW) (viz tab. 2.).

\section{DISKUSE}

Záměrem této práce bylo zjištění a posouzení změn jednotlivých parametrů tělesného složení vlivem předsoutěžní redukce tělesné hmotnosti u českých vrcholových judistů. Jak jsme předpokládali, značná část hmotnostního úbytku byla na úkor tělesné vody a to zejména extracelulární (ECW), která se v průměru snížila o 3,7 1, tj. o 13,8 \%. Yoshioka et al. (2006) ve své studii $(n=22$, průměrný věk $=19,5 \pm 0,6$ let) uvádí snížení celkové tělesné vody (TBW) o 3,4 $\pm 2,9 \%$ při průměrné redukci hmotnosti o $2,8 \mathrm{~kg}$. U našeho souboru činil 
úbytek celkové tělesné vody (TBW) 6,0 \%, přičemž ale průměrná redukce tělesné hmotnosti byla $3,8 \mathrm{~kg}$. V distribuci tekutin mezi intracelulární (ICW) a extracelulární (ECW) jsme zjistili velké individuální odlišnosti a to především u intracelulární tekutiny (ICW), kde se změna pohybovala ve velkém rozmezí, tj. od - 9,6 1 do $+7,2$ 1, množství extracelulární tekutiny $(\mathrm{ECW}) \mathrm{v}$ téměř všech případech kleslo. Tato variabilita v distribuci tekutin může být způsobena také tím, že jednotliví probandi neredukovali stejné množství kilogramů, tudíž se redukce u každého z nich může promítnout do jiných parametrů tělesného složení. Důležitou roli hraje také způsob a doba redukce.

Dále jsme zaznamenali pokles množství tukuprosté hmoty (FFM) v průměru o 4,0 \%, rel. 3,4 \% těl. hmotnosti (pokles FFM u jednotlivých probandů se pohyboval v rozmezí od 1,4 \% do 15,5\%). Tukuprostá hmota (FFM) zahrnuje netukové komponenty, jako jsou svaly, kosti, kůže a orgány (oproti aktivní tělesné hmotě (LBM) nezahrnuje esenciální tuk), a proto je její pokles nežádoucí. V již zmiňované studii Yoshioka et al. (2006) došlo ke snížení tukuprosté hmoty (FFM) z 69,9 \pm 7,7 kg před redukcí na 67,9 \pm 7,3 kg po redukci. Došlo tedy $\mathrm{k}$ poklesu o 2,0 kg (tj. 2,9\%), přičemž celková průměrná redukce hmotnosti u celého souboru byla $2,8 \mathrm{~kg}$ (tedy nižší než u našeho soubor). Umeda (2004) ve své studii ( $($ = 49) uvádí snížení tukuprosté hmoty (FFM) u judistů o $1,7 \mathrm{~kg}$ při průměrné redukci $2,8 \mathrm{~kg}$.

Nežádoucí je i pokles hodnoty buněčné hmoty (BCM), což je část tukuprosté hmoty (FFM), která zahrnuje metabolicky aktivní aerobní buňky kosterní a srdeční svaloviny, kostní tkáně a buňky vnitřních orgánů. Úroveň BCM patří mezi nejlepší ukazatele svalové činnosti, které mohou predikovat sportovní výkon (Andreoli et al., 2003). U sledovaného souboru se tato hodnota snížila o 1,8 \%. Pokles jsme zaznamenali i v množství extracelulární hmoty (ECM) a to o $9,8 \%$.

Poměr ECM/BCM se jeví jako důležité kritérium pro hodnocení dispozic k svalové práci. Pokles ECM/BCM je ve většině př́ípadů indikátorem zlepšení úrovně tělesného složení ve smyslu zlepšení kvality svalů. Jeho snížení však může být způsobené také ztrátou vody v extracelulárním prostoru. U vysoce trénovaných jedinců se tato hodnota pohybuje okolo 0,7 (Data Input, 2004). V našem souboru jsme zaznamenali průměrnou hodnotu poměru ECM/BCM $0,720 \pm 0,104$, přičemž vlivem snižování tělesné hmotnosti klesla tato hodnota v průměru na $0,656 \pm 0,078$, což představuje pokles o 0,064 , tedy o $8,9 \%$.

Často sledovaným parametrem tělesného složení je množství tělesného tuku, a to nejen odborníky, ale především samotnými sportovci. Jednoznačně se dá souhlasit s tím, že je to právě tělesný tuk, který v nadměrném množství negativně ovlivňuje pohybový výkon, resp. se zvyšujícím se množstvím tělesného tuku klesá výkon (Wilmore \& Costill, 1994). Vlivem redukce tělesné hmotnosti došlo ke snížení množství tělesného tuku z 12,9 $\pm 3,0 \%$ na hodnotu $11,2 \pm 2,9 \%$, tedy množství tuku se snížilo o 13,2 \%, rel. 2,1 \% těl. hmotnosti (rozmezí poklesu u jednotlivých probandů bylo od 2,7 \% do 31,2 \%). Je ale třeba zmínit, že množství tuku se počítá z celkové tělesné vody (TBW), tudíž velké výkyvy v objemu TBW mohou vést ke kolísání vypočítávaných hodnot tělesného tuku. Rovněž musíme připomenout, že metodou BIA nerozlišíme množství podkožního a strukturálního tuku, je možné zjistit jen celkové zastoupení tukové tkáně v organismu (Malá a kol., 2008). Yoshioka et al. (2006) ve své studii uvádí snížení procenta tělesného tuku při průměrné redukci $2,8 \mathrm{~kg}$ tělesné hmotnosti z $11,3 \pm 6,1 \%$ na $10,7 \pm 6,3 \%$, což představuje snížení tělesného tuku o 5,3 \% z původního množství. U našeho souboru byl tedy pokles procenta tělesného tuku více než dvojnásobný, ale je třeba zmínit, že u našeho souboru se také vyskytovala vyšší průměrná hodnota tělesného tuku před redukcí hmotnosti a došlo také $\mathrm{k}$ většímu poklesu tělesné hmotnosti, a to v průměru o 1,0 kg více než ve zmiňované studii.

\section{ZÁVĚRY}

Výsledky naší studie ukazují, že redukce tělesné hmotnosti u judistů se odráží v různé míře ve všech parametrech složení těla a je do určité míry ovlivněna individuální variabilitou jedince. U všech probandů došlo ke snížení celkové tělesné vody (TBW) a také procenta tuku, a to i přesto, že se jednalo o rychlou redukci tělesné hmotnosti trvající jen několik dní. U většiny probandů byl zjištěn také pokles tukuprosté hmoty (FFM), což je při předsoutěžní redukci tělesné hmotnosti nežádoucí. U dalších komponent tělesného složení jsme u našeho souboru zjistili individuální odlišnosti.

Na základě těchto výsledků se jeví metoda BIA vhodná pro toto testování, za předpokladu dodržení standardních podmínek měření a při použití vhodných predikčních rovnic, vzhledem k možnosti terénního využití a také pro její dostupnost a nenáročnost na obsluhu.

Problematika redukce tělesné hmotnosti velice úzce souvisí s problematikou výživy, proto by bylo vhodné z dlouhodobého hlediska nejen posuzovat každého probanda individuálně, ale také posuzovat u každého 
probanda stravovací zvyklosti a navrhnout vhodná doporučení, aby se docílilo žádaného snížení tělesné hmotnosti zároveň s udržením vysoké výkonnosti. Vhodné by bylo dlouhodobé sledování v průběhu jednotlivých period celého roku.

\section{LITERATURA}

Andreoli, A., Melchiorri, G., Brozzi, M., Di Marco, A., Volpes, S. L., Garofano, P., Di Daniele, N. \& De Lorenzo, A. (2003). Effect of different sports on body cell mass in highly trained athletes. Acta Diabetol, 40.

Data Input (2004). Manuál Nutri 4 - Multifrekvency Software for the Determination of Body Water, Body Composition and Nutritional Status. Instruction for Use, Firma Data Input GmBH, Trakenher Strasse 5, 60487, Frankfurt am Main, Germany.

Forbes, G. B. (1987). Human body composition. New York: Springer Verlag.

Havlíčková a kol. (1999). Fyziologie tělesné zátěže I. Obecná část. Praha: Karolinum.

Heyward, V., H., Stolarczyk, L., M. (1996). Applied body composition assessment. Champaign: Human Kinetics.

Horswill, C.A. (2009). Making Weight in Combat Sports. Combat Sports Medicine, Springer London, 21-39.

Ishiguro, N. et al. (2005). A comparison of tree bioelectrical impedance analyses for predicting lean body mass in a population with a large difference in muscularity. Eur. J. Appl. Physiol., r. 94, č. 1-2, s. 25-35.

Malá, L., Malý, T., Zahálka F. (2008). Profil telesného zloženia juniorských reprezentantov v jude. Česká kinantropologie, Vol. 12, č. 3, s. 94 -103.

Nedorostová, J. (1977). Shazování váhy. Československý sport.

Pařízková, J. (1998). Složení těla, metody měření a využití ve výzkumu a lékařské praxi. Med. sport. bohem. slov., 7 (1): 1-6.

Ransone, J., Hughest, B. (2004). Body-Weight Fluctuation in Collegiate Wrestlers: Implications of the National Collegiate Athletic Association Weight-Certification Program. Journal of Athletic Training, 39 (2), 162-168.

Roche, F. A., Heymsfield, S. B., Lohman, T. G. (1996). Human Body Composition. Human Kinetics.

Sinning, W. E. Body composition in athletes. In Roche, A. F., Heymsfield, S. B., Lohman, T. G. (eds.) (1996). Human body composition. Human Kinetic: Champaign.

Štěpánek, J. a kol. (1990). Judo (metodický popis). 1. vyd. Praha: Tělovýchovná škola.

Umeda, T., Nakaji, S., Shimoyama, T. et al. (2004). Adverse effects of energy restriction on changes in immunoglobulins and complements during weight reduction in judoists. Journal of Sports Medicine \& Physical Fitness, Vol. 44 Issue 3, 328-334.

Wilmore, J. H., Costill, D. L. (1994). Physiology of Sport and Exercise. Human Kinetics, Champaign.

Yoshioka, Y., Umeda, T., Nakaji, S., Kojima, A., Tanabe, M., Mochida, N., Suguwara, K. (2006). Gender Differences in the Psychological Response to Weight Reduction in Judoists. International Journal of Sport Nutrition and Exercise Metabolism, Human Kinetics, Japan, 16, 187-198. 